\title{
未唒亚硫酸パルプの過䣷酸漂白について
}

\author{
山形大学農学部谷口栄一
}

\section{Peracetic acid Bleaching of Unbleached Sulfite Pulp}

\section{Eiichi Taniguchi}

Faculty of Agriculture, Yamagata University

This work was initiated in order to investigate peracetic acid (PA) bleaching different from $\mathrm{NaClO}_{2}, \mathrm{H}_{2} \mathrm{O}_{2}$ and hypochlorite bleaching.

Active groups content, copper number, viscosity and hemicellulose content in various bleached pulps were measured.

Under same bleaching condition, PA bleaching showed higher viscosity of pulp than hypochlorite bleaching but it showed lower viscosity of pulp than $\mathrm{H}_{2} \mathrm{O}_{2}$ and $\mathrm{NaClO}_{2}$ bleaching. It seemed that PA bleached pulps showed the lowest brightness among these bleached pulps, but hemicellulose content in PA bleached pulps showed high value.

At initial stage of PA bleaching CO group content in pulps increased, but it decreased with the progress of bleaching.

By means of mixing $\mathrm{NaClO}_{2}$ with PA brightness was improved and showed higher viscosity than PA bleaching. At $80^{\circ} \mathrm{C}$ and $90^{\circ} \mathrm{C}$ PA bleaching proceeded speedily and made perfect in a few minutes, although it took about 2 or 3 hours at $60^{\circ} \mathrm{C}$.

\section{1. 緒言}

過酢酸（P A と略記）漂白について，主として活性 基の挙動関する研究(1)(2) を行ない，へミセルローズ 抽出処理による CO 基量の減少など，色戻りに関す る基碟的知見を得た。

今回, さらにU・SP について塩素化, $\mathrm{NaOH}$ 抽出 $\mathrm{PA}$ 漂白, $\mathrm{NaClO}_{2}$ 漂勺, $\mathrm{PA}$ と $\mathrm{NaClO}_{2}$ 混合漂白, $\mathrm{H}_{2} \mathrm{O}_{2}$ 漂白, Hypochlorite (漂白粉) 漂白について, 1 段方いは 3 段漂白を行ない，酒白パルプの活性基， 銅洒, 粘度, へミセルローズ含有量を求め, P A 漂白 と他の漂白鼡を比较検討した。特に，P A 漂白につい ては濃度の影響，処理温度の影響，P A 消費率につい ても検討し，PA罢白の知見を得んとしたものである。

\section{2. 材料ならびに実験方法}

\section{工場製品アカマツ U・SP を使用した。}

漂白に際しては，風乾 U·SP $11.8 \mathrm{~g}$ （無水物 $10 \mathrm{~g}$ ) を用い，塩素化は塩素添加量 $2 \%$ (対パルプ), 処理 温度 $13 \sim 15^{\circ} \mathrm{C}$, 処理時間 30 分である。塩素化後, 直 ちに水洗, アセトン洗浄し， $60^{\circ} \mathrm{C}$ で乾燥した。この 洗浄乾燥の操作は以下の各種の漂白パルプについて子 同様に行なったものである。またパルプ濃度は全て 3
\%である。

第 2 段の $\mathrm{NaOH}$ 処理は, $\mathrm{NaOH}$ を $2 \%$ (対パル プ）添加し， $60^{\circ} \mathrm{C}, 60$ 分処理した。

第 3 段の各種漂白剂処理は, $\mathrm{PA}, \mathrm{PA} \cdot \mathrm{NaClO}_{2}, \mathrm{Na}$ $\mathrm{ClO}_{2} \quad \mathrm{H}_{2} \mathrm{O}_{2}$, Hypochlorite (有効塩素) を4\% (対パ ルプ）添加したものである。 $\mathrm{PA} \cdot \mathrm{NaClO}_{2}$ はそれぞれ 単独に $2 \%$ ずつ添加し，その和が $4 \%$ となるようにし たものである。

また，これら各種漂白剂の $10 \%$ (対パルプ) 添加 による 1 段処理を行ない, $60^{\circ} \mathrm{C}$ において, 60 分, 120 分, 180 分漂白処理して試料とした。 これらの漂白条件を一括すれば第 1 表のごとくであ る。本表の茜白条件の $\mathrm{pH}$, 温度は，たとえば，No. 2 の $2 \% \mathrm{Cl}-2 \% \mathrm{NaOH}$ では, $\mathrm{NaOH}$ 処理時の $\mathrm{pH}$ 璐よび温度を示すもので第1段の塩素化の $\mathrm{pH}$ ，温度 は No.1 と同じである。以下これにならって，最終 処理段時の $\mathrm{pH}$, 温度を表示するものである。

また，以上各種漂白パルプのアルカリ精製を行なっ た。これは $10 \% \mathrm{NaOH}$ (対パルプ) を添加しパルプ 濃度 $3 \%, 60^{\circ} \mathrm{C}, 60$ 分である。 $\mathrm{pH}$ 以初期 13.2, 終期 12.2 であった。

さらに， $\mathrm{pH}$ 漂白については，20〜576\%（対パル

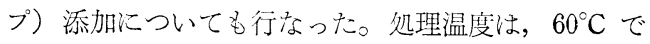


Table 1 Bleaching conditions of $\mathrm{U} \cdot \mathrm{SP}$

\begin{tabular}{|c|c|c|c|c|c|c|}
\hline \multirow{2}{*}{ No. } & \multirow{2}{*}{ Bleaching process } & \multirow{2}{*}{$\begin{array}{c}\text { Pulp } \\
\text { consistency }(\%)\end{array}$} & \multirow{2}{*}{ Temp. $\left({ }^{\circ} \mathrm{C}\right)$} & \multirow{2}{*}{ Time (min) } & \multicolumn{2}{|c|}{$\mathrm{pH}$} \\
\hline & & & & & initial & final \\
\hline 1 & $2 \%$ & 3 & $13 \sim 15$ & 30 & 2.6 & 2.5 \\
\hline 2 & $\begin{array}{l}2 \% \\
\mathrm{Cl}-\mathrm{NaOH}\end{array}$ & 3 & 60 & 60 & 11.3 & 10.9 \\
\hline 3 & $\begin{array}{l}2 \% \quad 2 \% \quad 4 \% \\
\mathrm{Cl}-\mathrm{NaOH}-\mathrm{PA}\end{array}$ & 3 & 60 & 60 & 3.5 & 3.7 \\
\hline 4 & $\underset{\mathrm{Cl}-\mathrm{NaOH}-}{2 \%} \begin{array}{lll}2 \% & \mathrm{PA} \\
2 \% & \mathrm{NaClO}_{2}\end{array}$ & 3 & 60 & 60 & 3.9 & 3.4 \\
\hline 5 & $\begin{array}{l}2 \% 2 \% \quad 4 \% \\
\mathrm{Cl}-\mathrm{NaOH}-\mathrm{NaClO}_{2}\end{array}$ & 3 & 60 & 60 & 3.5 & 3.8 \\
\hline 6 & $\begin{array}{l}2 \% \quad 2 \% \quad 4 \% \\
\mathrm{Cl}-\mathrm{NaOH}-\mathrm{H}_{2} \mathrm{O}_{2}\end{array}$ & 3 & 60 & 60 & 10.8 & 10.4 \\
\hline 7 & $\begin{array}{l}2 \% 2 \% \quad 4 \% \\
\mathrm{Cl}-\mathrm{NaOH}-\mathrm{Hypochlorite}\end{array}$ & 3 & 60 & 60 & 10.5 & 10.3 \\
\hline 8 & & 3 & 60 & 60 & 3.2 & 3.1 \\
\hline 9 & $10 \%$ PA & 3 & 60 & 120 & 3.4 & 3.2 \\
\hline 10 & & 3 & 60 & 180 & 4.4 & 4.0 \\
\hline 11 & & 3 & 60 & 60 & 3.5 & 3.5 \\
\hline 12 & $\mathrm{PA}+\mathrm{NaClO}_{2}$ & 3 & 60 & 120 & 4.1 & 4.1 \\
\hline 13 & & 3 & 60 & 180 & 4.3 & 3.9 \\
\hline 14 & & 3 & 60 & 60 & 10.3 & 9.2 \\
\hline 15 & $10 \% \quad \mathrm{H}_{2} \mathrm{O}_{2}$ & 3 & 60 & 120 & 10.2 & 9.7 \\
\hline 16 & & 3 & 60 & 180 & 10.3 & 9.8 \\
\hline 17 & & 3 & 60 & 60 & 11.6 & 6.4 \\
\hline 18 & $10 \%$ Hypochlorite & 3 & 60 & 120 & 10.8 & 6.3 \\
\hline 19 & & 3 & 60 & 180 & 10.5 & 6.5 \\
\hline 20 & & 3 & 60 & 60 & 3.1 & 3.1 \\
\hline 21 & $20 \% \mathrm{PA}$ & 3 & 60 & 120 & 3.5 & 3.4 \\
\hline 22 & & 3 & 60 & 180 & 3.3 & 3.4 \\
\hline 23 & & 3 & 60 & 60 & 3.0 & 3.0 \\
\hline 24 & $30 \% \mathrm{PA}$ & 3 & 60 & 120 & 3.4 & 3.4 \\
\hline 25 & & 3 & 60 & 180 & 3.4 & 3.2 \\
\hline 26 & & 3 & 60 & 60 & 2.8 & 2.7 \\
\hline 27 & $50 \%$ PA & 3 & 60 & 120 & 3.4 & 3.2 \\
\hline 28 & & 3 & 60 & 180 & 3.2 & 3.1 \\
\hline 29 & & 3 & 60 & 60 & 2.8 & 2.7 \\
\hline 30 & $70 \% \quad \mathrm{PA}$ & 3 & 60 & 120 & 3.5 & 3.0 \\
\hline 31 & & 3 & 60 & 180 & 3.3 & 3.0 \\
\hline 32 & & 3 & 60 & 60 & 2.6 & 2.6 \\
\hline 33 & $100 \% \quad \mathrm{PA}$ & 3 & 60 & 120 & 3.0 & 3.0 \\
\hline 34 & & 3 & 60 & 180 & 3.0 & 2.9 \\
\hline
\end{tabular}

あるが， $80^{\circ} \mathrm{C}, 90^{\circ} \mathrm{C}$ についても実験した。

以上, 各種の試料パルプについて前報(1)(2) と同様に $\mathrm{CO}$ 基量 $^{(3)}$, $\mathrm{COOH}$ 基量 ${ }^{(4)}$, 銅価 ${ }^{(5)}$, 粘度 (銅安法) を测定した。へミセルローズ ${ }^{(6)}$ は，18\% NaOH 溶解 分をへミセルローズとして算出したものである。

\section{3. 実験結果ならびに考察}

第 1 図より，U・SP 塩素化により $\mathrm{CO}$ 基量が著し く増加する特摧を示している。次に $\mathrm{NaOH}$ 抽出処理 によるクロールリグニン溶出となり CO 基量の減少が 昭和 42 年 10 月
顕著である。したがって塩素化により增加した CO 菇量は，クロールリグニンに関連するもので，塩素化 により新生したものと䓅光られる。

次に，3段処理で CO 嚄量の消長は漂白戍の種類に より異なることを示し， $\mathrm{PA}$ 漂白パルプ $\mathrm{PA} \cdot \mathrm{NaClO}_{2}$ 漂白パルプは $\mathrm{NaOH}$ 抽出段階のパルプと比校して, $\mathrm{CO}$ 基量が增加し, $\mathrm{NaClO}_{2}$ 漂白パルプは大差がなく, $\mathrm{H}_{2} \mathrm{O}_{2}$ 扝よび Hypoch!orite 漂白パルプでは低下して いる。このよらな $\mathrm{CO}$ 基量の消長は, 漂白処理時の が低い酸性侧で，CO 基量を増加し，これに反し $\mathrm{PH}$ 


谷学只

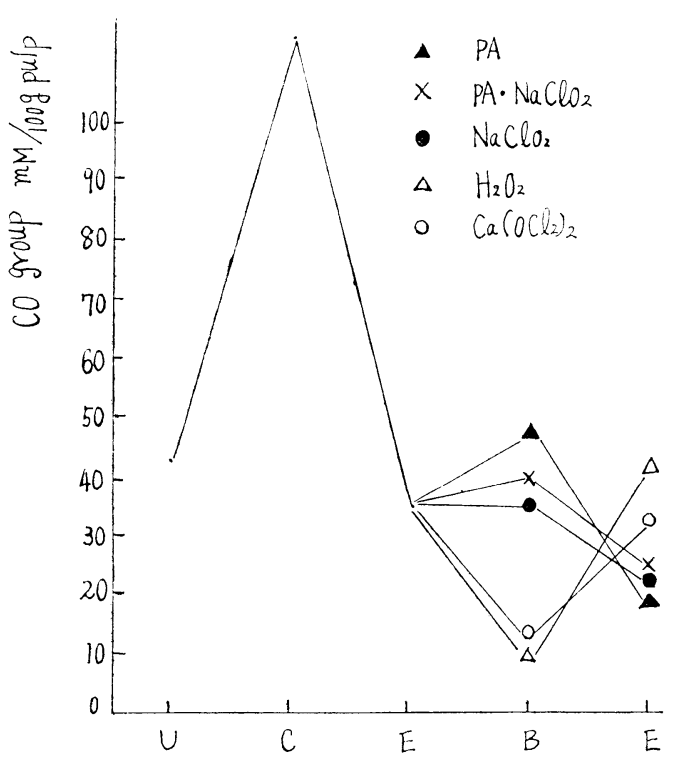

Fig. 1 Changes of carbonyl group at va rious stages of bleaching
U Unbleached
C Chlorinated
E $\mathrm{NaOH}$ extracted
B Bleached
PA Peracetic acid

アルカリ性で低下することを示すものとみられる ${ }^{(7)(8)}$ 。 第 2 図より, $\mathrm{COOH}$ 基量は塩素化, $\mathrm{NaOH}$ 抽出処 理で㳈減を示しているが，これらの処理は緩和な作用 であることによると考えられる。

3 段処理で各種漂白剤による影響は，P A 漂白パル プが 2 段よりわずかに増加し，その他の漂白パルプで は減少している。

第 4 段の $10 \% \mathrm{NaOH}$ 抽出処理による各種漂白パル

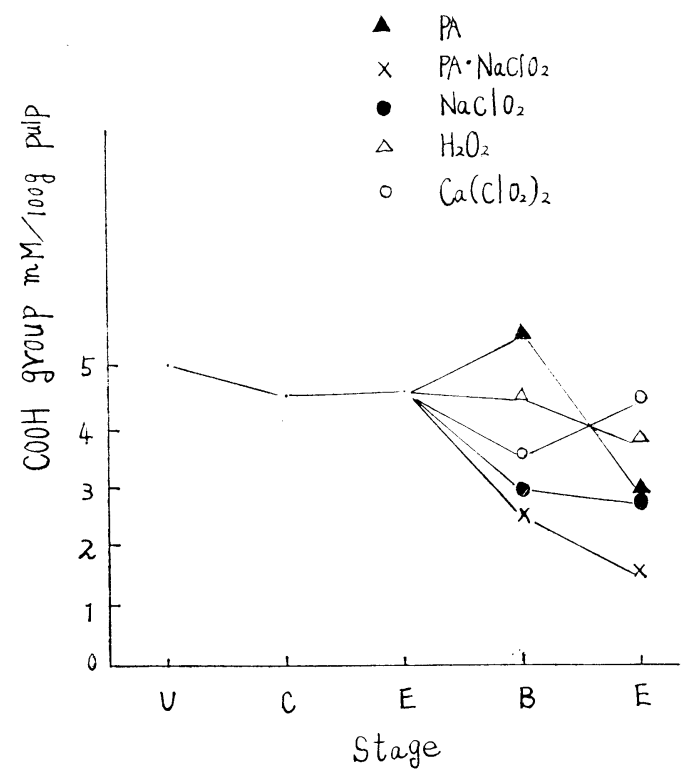

Fig. 2 Changes of carboxyl group at various stages of bleaching

U Unbleached

C Chlorinated

E $\mathrm{NaOH}$ extracted

B Bleached

プの CO 基量については Hypochlorite 漂白パルプ, $\mathrm{H}_{2} \mathrm{O}_{2}$ 漂白パルプが 3 段処理時より増加し $\mathrm{COOH}$ 基 では Hypochlorite 漂白パルプが増加しているが，概 して $10 \% \mathrm{NaOH}$ 抽出処理は，これらの活性基を低 下寸るものと考えられた。(第 1 図，第 2 図参照）

第 2 表より，粘度は $\mathrm{NaClO}_{2}, \mathrm{H}_{2} \mathrm{O}_{2}$ 漂白パルプが 高く, Hypochlorite 漂白パルプが最も低い。PA・ $\mathrm{NaClO}_{2}$ 混合漂白パルプは, P A 漂白パルプより高く,

Table 2 Copper number, viscosity and hemicellulose in various bleached pulps and $10 \% \mathrm{NaOH}$ extracted pulps

\begin{tabular}{|l|c|c|c|c|c|}
\hline \multirow{2}{*}{ Bleaching process } & \multicolumn{3}{|c|}{ Bleached pulp } & After $10 \%$ NaOH extracted \\
\cline { 2 - 6 } & Copper number & Viscosity & Hemicellulose & Viscosity & Hemicellulose $\%$ \\
\hline $\mathrm{U} \cdot \mathrm{SP}$ & 0.98 & - & - & - & - \\
$2 \% \mathrm{Cl}$ & 1.70 & - & 13.57 & - & 10.91 \\
$2 \% \mathrm{Cl}-\mathrm{NaOH}$ & 1.27 & - & 11.36 & - & 10.48 \\
$2 \% \mathrm{Cl}-\mathrm{NaOH}-4 \% \mathrm{PA}$ & 1.48 & 4.00 & 14.00 & 3.35 & 12.52 \\
$2 \% \mathrm{Cl}-\mathrm{NaOH}-\left\{\begin{array}{l}2 \% \mathrm{PA} \\
2 \% \mathrm{NaClO}\end{array}\right.$ & 1.12 & 4.80 & 13.60 & 4.60 & 12.50 \\
$2 \% \mathrm{Cl}-\mathrm{NaOH}-4 \% \mathrm{NaClO}_{2}$ & 1.27 & 5.64 & 12.34 & 5.40 & 11.15 \\
$2 \% \mathrm{Cl}-\mathrm{NaOH}-4 \% \mathrm{H}_{2} \mathrm{O}_{2}$ & 1.20 & 5.69 & 11.84 & 5.36 & 10.52 \\
$2 \% \mathrm{Cl}-\mathrm{NaOH}-4 \% \mathrm{Ca}(\mathrm{OCl}) \mathrm{Cl}$ & 1.41 & 3.44 & 11.58 & 3.40 & 10.20 \\
\hline
\end{tabular}


$\mathrm{NaClO}_{2}$, 漂白パルプより低く, $\mathrm{PA}$ と $\mathrm{NaClO}_{2}$ それ ぞれ単独の漂白パルプの中間の粘度值を示している。

銅価俚 1.1〜1.5 の範囲で，漂白剂の種類による相違 は少ないが, P A 漂白パルプ, Hypochlorite 漂白パ ルプが，その他の漂白パルプより高い。

ところで，後述の実験においてもみられたが，同一 条件汇捻いて，PA漂白パルプは他の漂白パルプより も白色度が持とっていることが観察された。このよう にP A法が白色度が抢とっていることは島田氏等(9)の 結果汇もみられる。しかし， $\mathrm{NaClO}_{2}$ をPAに混合し て漂白することにより白色度の向上すること，李た粘 度も PA単独より高くなり, $\mathrm{PA} \cdot \mathrm{NaClO}_{2}$ 混合漂白 が有利であることがみられた。なお， $\mathrm{NaClO}_{2}$ 処理で は活性化のため酸性にする必要があるが，P A と Na$\mathrm{ClO}_{2}$ の混合では, 新たに酸添加の必要はない。

へミセルローズ含有量は P A 潈白パルプが大で，こ れについで $\mathrm{PA} \cdot \mathrm{NaClO}_{2}$ 混合漂白パルプであった。 これ虫，PA漂白はへミセルローズ保持が大である河 野氏等の結果(10) と一致するものである。また P A ハ ルプの CO 基量の多い原因も，このへミセルロース が一因とみられる。10\% NaOH 抽出処理は, へミセ ルロース含有量を低下し，また前述のように概して活 性基を低下さすととからパルプ精製の一助とみられた。 第 3 図より, $10 \%$ 漂白剛（対パルプ）による 1 段漂 白に招いて，CO 基量は漂白剂の種類により異なり，

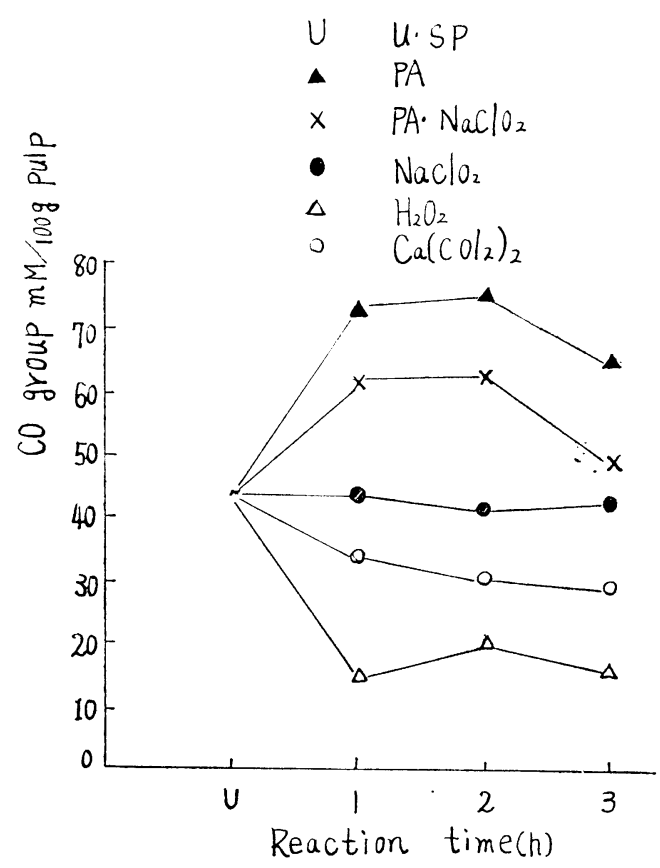

Fig. 3 Changes of carbonyl group in various pulps by reaction times

$\mathrm{PA}$ 漂白パルプが最も多く, U・SP より増加し，つい で, $\mathrm{PA} \cdot \mathrm{NaClO}_{2}$ 混合漂白パルプで, $\mathrm{NaClO}_{2}$ 漂白パ ルブは U.SP と大羑なく, Hypochlorite 漂白パルプ,

Table 3 Carboxyl, group viscosity and hemicellulose in various bleached pulps and $10 \% \mathrm{NaOH}$ extracted pulps

\begin{tabular}{|c|c|c|c|c|c|}
\hline \multirow{2}{*}{$\begin{array}{l}\text { Chemical addition } \\
\text { (\% to dry pulp) }\end{array}$} & \multirow{2}{*}{$\begin{array}{c}\text { Time } \\
(\mathrm{hr})\end{array}$} & \multicolumn{3}{|c|}{ Bleached Pulp } & \multirow{2}{*}{$\begin{array}{l}\text { After } 10 \% \mathrm{NaOH} \\
\text { extracted } \\
\text { Hemicellulose }(\%)\end{array}$} \\
\hline & & $\begin{array}{l}\mathrm{COOH} \mathrm{mM} \\
/ 100 \mathrm{~g} \text { pulp }\end{array}$ & Viscosity & Hemicellulose (\%) & \\
\hline \multirow{3}{*}{$10 \% \mathrm{PA}$} & 1 & 6.53 & 4.44 & 14.66 & 13.00 \\
\hline & 2 & 5.32 & 4.12 & 15.84 & 13.13 \\
\hline & 3 & 4.97 & 4.16 & 16.00 & 11.82 \\
\hline \multirow{3}{*}{$5 \% \mathrm{PA}+5 \% \mathrm{NaClO}_{2}$} & 1 & 5.04 & 6.90 & 12.96 & 10.99 \\
\hline & 2 & 2.73 & 7.30 & 12.67 & 11.66 \\
\hline & 3 & 2.70 & 6.90 & 13.00 & 11.66 \\
\hline \multirow{3}{*}{$10 \% \mathrm{NaClO}_{2}$} & 1 & 5.37 & 7.90 & 12.92 & 11.70 \\
\hline & 2 & 4.71 & 6.57 & 12.59 & 11.42 \\
\hline & 3 & 2.54 & 7.90 & 12.63 & 10.48 \\
\hline \multirow{3}{*}{$10 \% \mathrm{H}_{2} \mathrm{O}_{2}$} & 1 & 4.71 & 6.50 & 12.42 & 10.64 \\
\hline & 2 & 4.21 & 6.50 & 11.73 & 10.56 \\
\hline & 3 & 4.58 & 6.35 & 12.42 & 10.25 \\
\hline \multirow{3}{*}{$10 \% \mathrm{Ca}(\mathrm{OCl}) \mathrm{Cl}$} & 1 & 2.73 & 3.39 & 14.04 & 11.66 \\
\hline & 2 & 2.47 & 3.20 & 14.62 & 11.66 \\
\hline & 3 & 5.37 & 3.15 & 14.33 & 12.13 \\
\hline
\end{tabular}


$\mathrm{H}_{2} \mathrm{O}_{2}$ 漂白パルブは U.SPより減少している。しかし

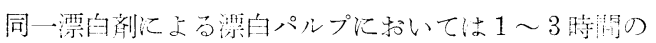

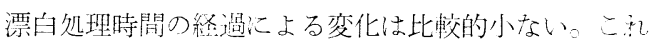

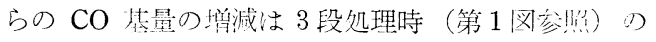
漂白剂の影響さ同-.ーであった。

第 3 表より，P A 漂白パルプの粘度は Hypochlorite 漂白パルプより高いが，その他の伍白白パルプより低い ことを示す。へミセルローズ含有㫣は P A 愣白パルプ が多いこと, $\mathrm{PA} \mathrm{NaClO}_{2}$ 混合湴内パルプは $\mathrm{PA}$ 漂白 パルプより粘度が高く, 白色度す间上していることも 前述と同様であった。 $\mathrm{COOH}$ 梦量は Hypochlorite 漂白パルプが 3 時間処理により増加しているが，粘度 が他の漂白パルブより低いことからセルロースの崩填 による増加とみられる。 $\mathrm{PA} \cdot \mathrm{NaClO}_{2}$ 混合漂白パルプ, $\mathrm{NaClO}_{2}$ 漂白パルプは処理時間の経過により $\mathrm{COOH}$ 基量が低下しているが，これらのパルプは粘度も高く， セルローズの崩壊はみられないから, 処理時間の経過 による低分子物質除去の精製作用による $\mathrm{COOH}$ 基の 低下と考光られる。10\% NaOH 抽出処理後は，P A 漂白パルプのヘミセルローズ含有量も他の漂白パルブ と近似となり，ヘミセルローズの抽出作用がみとめら れる。

第 4 図より，10〜100\% P A漂白パルプの CO 基量 の消長は, いずれのP A 漂白パルプも 1 時間処理によ

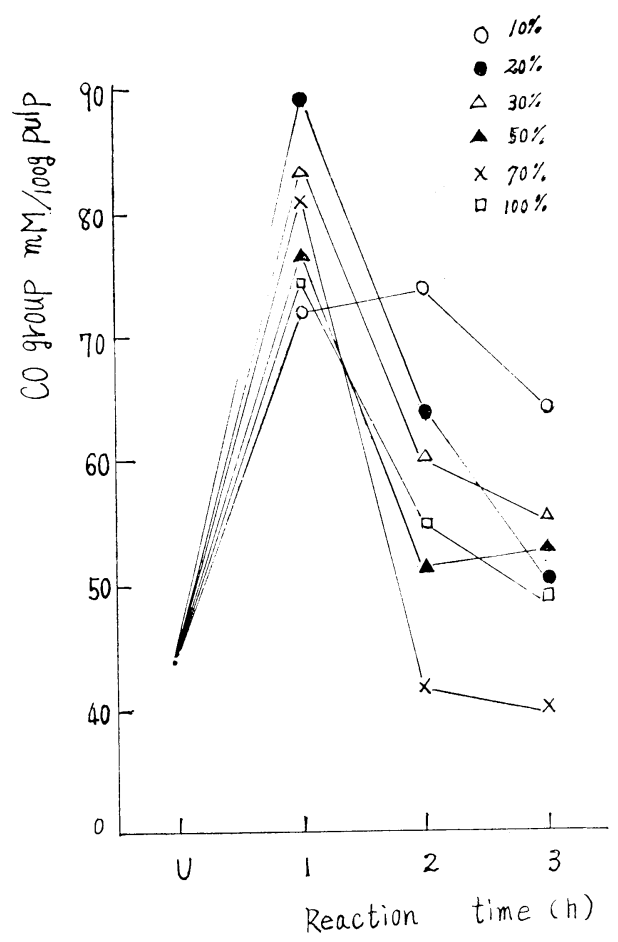

Fig. 4 Changes of carbonyl group in various PA bleaching pulps by reaction times

Table 4 Carboxyl group, copper number, viscosity and hemicellulose in various $\mathrm{PA}$ bleaching pulps

\begin{tabular}{|c|c|c|c|c|c|}
\hline $\begin{array}{l}\text { Chemical addition } \\
(\% \text { to dry pulp })\end{array}$ & $\underset{(\mathrm{hr})}{\mathrm{Time}}$ & $\begin{array}{l}\text { COOH mM } \\
/ 100 \mathrm{~g} \text { pulp }\end{array}$ & Copper number & Viscosity & Hemicellulose $\%$ \\
\hline \multirow{3}{*}{$10 \mathrm{PA}$} & 1 & 6.53 & 2.56 & 4.44 & 14.66 \\
\hline & 2 & 5.32 & 2.59 & 4.22 & 15.84 \\
\hline & 3 & 4.97 & 2.61 & 4.15 & 16.00 \\
\hline \multirow{3}{*}{$20 \mathrm{PA}$} & 1 & 6.67 & 2.32 & 4.78 & 14.46 \\
\hline & 2 & 5.39 & 2.30 & 4.36 & 15.44 \\
\hline & 3 & 4.58 & 2.35 & 4.10 & 15.25 \\
\hline \multirow{3}{*}{$30 \mathrm{PA}$} & 1 & 5.18 & 2.33 & 4.61 & 15.25 \\
\hline & 2 & 4.60 & 2.11 & 4.77 & 14.46 \\
\hline & 3 & 4.46 & 2.10 & 4.49 & 14.82 \\
\hline \multirow{3}{*}{$50 \mathrm{PA}$} & 1 & 4.85 & 2.08 & 4.44 & 15.72 \\
\hline & 2 & 4.54 & 1.98 & 4.93 & 14.78 \\
\hline & 3 & 4.40 & 1.77 & 4.75 & 15.08 \\
\hline \multirow{3}{*}{$70 \mathrm{PA}$} & 1 & 5.47 & 2.30 & 4.53 & 15.47 \\
\hline & 2 & 4.61 & 2.11 & 4.67 & 14.40 \\
\hline & 3 & 4.44 & 2.11 & 4.69 & 15.08 \\
\hline \multirow{3}{*}{$100 \mathrm{PA}$} & 1 & 5.72 & 2.32 & 4.90 & 14.82 \\
\hline & 2 & 4.54 & 1.88 & 4.88 & 14.35 \\
\hline & 3 & 4.51 & 1.77 & 4.93 & 14.01 \\
\hline
\end{tabular}


り, U・SPより著しい橧加がみられる。2 時間処理に おいて，10\% P A 漂白パルプは 1 時間処理時と大差 がないが， $20 \%$ 以上のP A 漂白パルプでは著しく減少 している。3 時間処理にお污る減少は緩慢である。

これらの結果から，P A 漂白は初期の脱リグニン作 用により CO 基量を增加するが，処理時間の経過に よる脱リグニンの進行とともに，CO 基を減少し，白
任度尼问上するものとみられる。

第 4 表より $\mathrm{COOH}$ 基量は P A の濃度に拘らず近似 で，先しろ処理時間の経過汇よる低下の傾向がみられ る。銅価子大差はないが，高濃度の P A 漂白パルプの 方が銅価が低く，処理時間の影響は 3 時間処理の方が 1 時間処理よりも銅価が低い傾向もらかがわれる。へ ミセルローズ含有量は 14〜15\%でP A以外の漂白パ

Table 5 Carboxyl group, copper number, viscosity and hemicellulose in PA bleaching pulp at $60^{\circ} \mathrm{C}, 80^{\circ} \mathrm{C}$ and $90^{\circ} \mathrm{C}$

\begin{tabular}{|c|c|c|c|c|c|c|}
\hline $\begin{array}{c}\text { Chemical addition } \\
(\% \text { to dry pulp })\end{array}$ & $\begin{array}{c}\text { Times } \\
(\mathrm{min})\end{array}$ & $\begin{array}{c}\text { Temp. } \\
\left({ }^{\circ} \mathrm{C}\right)\end{array}$ & $\begin{array}{c}\text { COOH } \\
\mathrm{mM} / 100 \mathrm{~g} \text { pulp }\end{array}$ & $\begin{array}{c}\text { Copper } \\
\text { number }\end{array}$ & Viscosity & $\begin{array}{c}\text { Hemicellulose } \\
(\%)\end{array}$ \\
\hline $576 \% \mathrm{PA}$ & 60 & 60 & 4.07 & 1.57 & 4.77 & 13.47 \\
& 120 & 60 & 3.48 & 1.84 & 3.90 & 14.13 \\
& 180 & 60 & 2.02 & 1.98 & 3.74 & 14.33 \\
& 15 & 80 & 3.25 & 1.98 & 4.02 & 14.05 \\
& 60 & 80 & 4.42 & 2.39 & 3.00 & 16.72 \\
& 4 & 90 & 3.30 & 2.05 & 3.61 & 14.37 \\
& 60 & 90 & 4.8 & 2.80 & 2.50 & 18.66 \\
\hline
\end{tabular}

ルプより多いこと（第 2 表参照）ならびにP A 濃度に かかわらずへミセルローズ保持力が大であることがわ かる。

また，これら 10〜100\% P A 漂白パルプの中で 3 時間処理の $100 \% \mathrm{PA}$ 漂白パルプが，もっとも白色 度が向上していることが観察された。

第 5 表より $576 \%$ P A \%漂白の 1 時間， 2 時間処 理では，パルプは，な打淡黄色を残存しているが， 3 時間処理では白色に完全に漂白された。しかし $80^{\circ} \mathrm{C}$, $90^{\circ} \mathrm{C}$ ではとれぞれ 15 分和よび 4 分で白色となり， 1 時間処理では粘度低下, $\mathrm{COOH}$ 基量, 銅価の増加が みられた。ヘミセルローズ含有量は, $80^{\circ} \mathrm{C}, 90^{\circ} \mathrm{C}, 1$ 時間処理が著しく多いが，パルプの崩壊により $\mathrm{NaOH}$ 溶解部分が増加したことを示するのである。

以上のように，処理温度 $60^{\circ} \mathrm{C}$ では P Aの高濃度の 場合においても，処理時間の延長沈かかわらずパルプ を崩壞することは比較的少なく処理時間の経過により 徐々に白色度を向上する。すた処理温度の上昇により

Table 6 PA consumption under various bleaching conditions

\begin{tabular}{|c|c|c|c|c|}
\hline $\begin{array}{c}\text { Chemical addition } \\
(\% \text { to dry pulp })\end{array}$ & $\mathrm{pH}$ & Temp. $\left({ }^{\circ} \mathrm{C}\right)$ & Time (min.) & Consumption \% \\
\hline $10 \mathrm{PA}$ & $3.0 \sim 3.1$ & 60 & $60 \sim 180$ & $33 \sim 55$ \\
$20 \mathrm{PA}$ & $3.0 \sim 3.4$ & 60 & $60 \sim 180$ & $26 \sim 35$ \\
$30 \mathrm{PA}$ & $3.0 \sim 3.4$ & 60 & $60 \sim 180$ & $17 \sim 24$ \\
$50 \mathrm{PA}$ & $2.7 \sim 3.1$ & 60 & $60 \sim 180$ & $11 \sim 16$ \\
$70 \mathrm{PA}$ & $2.7 \sim 3.0$ & 60 & $60 \sim 180$ & $11 \sim 22$ \\
$100 \mathrm{PA}$ & $2.6 \sim 3$ & 60 & $60 \sim 180$ & $13 \sim 16$ \\
& $1.8 \sim 2.2$ & 60 & $60 \sim 180$ & $7 \sim 26$ \\
& & 80 & 15 & 24 \\
& & 80 & 60 & 40 \\
& & 90 & 4 & 24 \\
\hline
\end{tabular}

反応速度は迅速となりすみやかに漂白するとともに， 処理時間の延長はパルプを崩填さすものである。

第 6 表より，P A 漂白処理時のP A の消費を検討す ると, 攪拌, カバー用の時計四の開閉などの実験操作 中の P A の蒸散により定量的に求めることは困難のよ
らであったが，P A 添加量の多い方がP A 消費は多い が，添加量に対する消費量の比すなから消費率\%は少 ない。これがP Aの高濃度にかかわらずパルプの崩壊 が少ない一原因とみられる。しかし処理温度の上昇に より消費率の増加がみられパルプの崩壊も顕著となる 
ものと考察された。

総括

$\mathrm{U} \cdot \mathrm{SP}$ 漂白に抢沙る活性基の消長を追究し, 塩素化 で著しく $\mathrm{CO}$ 基量を増加するが $\mathrm{NaOH}$ 抽出化より 低下すること，また $\mathrm{PA}$ 漂白， $\mathrm{NaClO}_{2}$ 漂白は $\mathrm{CO}$ 基量を增加するが, $\mathrm{H}_{2} \mathrm{O}_{2}$ 漂白, Hypochlorite 漂白 では $\mathrm{CO}$ 基量を減少する。また P A 漂白は漂白初期 に CO 基量を增加するが，処理時間の経過により減 少することが判明した。

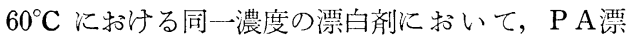
白パルプは Hypochlorite 漂白パルプよりは，パルプ 粘度は高いが, $\mathrm{NaClO}_{2}$ 漂白パルプ, $\mathrm{H}_{2} \mathrm{O}_{2}$ 櫒白パル プよりは低い。

白色度はP A漂白がこれらの漂白剤の中では低く， また漂白所要時間も長い。しかしP A $\mathrm{NaClO}_{2}$ を 混合した場合は，学独の場合より粘度，白色度が向上 し有利と考兄られた。P A 添加量が著しく增加した 場合でも，パルプの崩摆は少なく，へミセルローズの 保持も大である。P A漂白にお於るP A の消費量はP $\mathrm{A}$ 添加量の増加の割合に比較すれば少ない。処理温度 $80^{\circ} \mathrm{C}, 90 \mathrm{C}^{\circ}$ では反応速度が迅速になり, 数分間で漂 白が完了し，処理時間の延長によりパルプの酸化崩壞 が西らわれる。

本実験什力された蓮池伊保子嬢偪謝意を表わす。 引 用 文 献

（1）谷口栄一 紙 枝拹誌 $19283(1965)$

(2) 同上同上 $20140(1966)$

（3）杉松昭人，竹原繁雄 同 上 $14516(1960)$

（4）祖父汇寬，大久保正道，神南晴一

工化誌 $57247(1954)$

（5）訳文委員会 Tappi Standard 第1 部パルプ試 験法

314 (1958)

(6) 同上同上增 78 (1958)

(7) 朝倉書店 大有機化学 1934 (1960)

(8) Sven A. Rydholm Pulping Processes 964 (1965)

（9）島田五佐生, 河野通能, 近藤民雄 紙パ技協誌 12151 (1967)

(10) 河野通能，近藤民雄 紙パ技協誌 19347 (1965) (原稿受付昭 42.6.5)

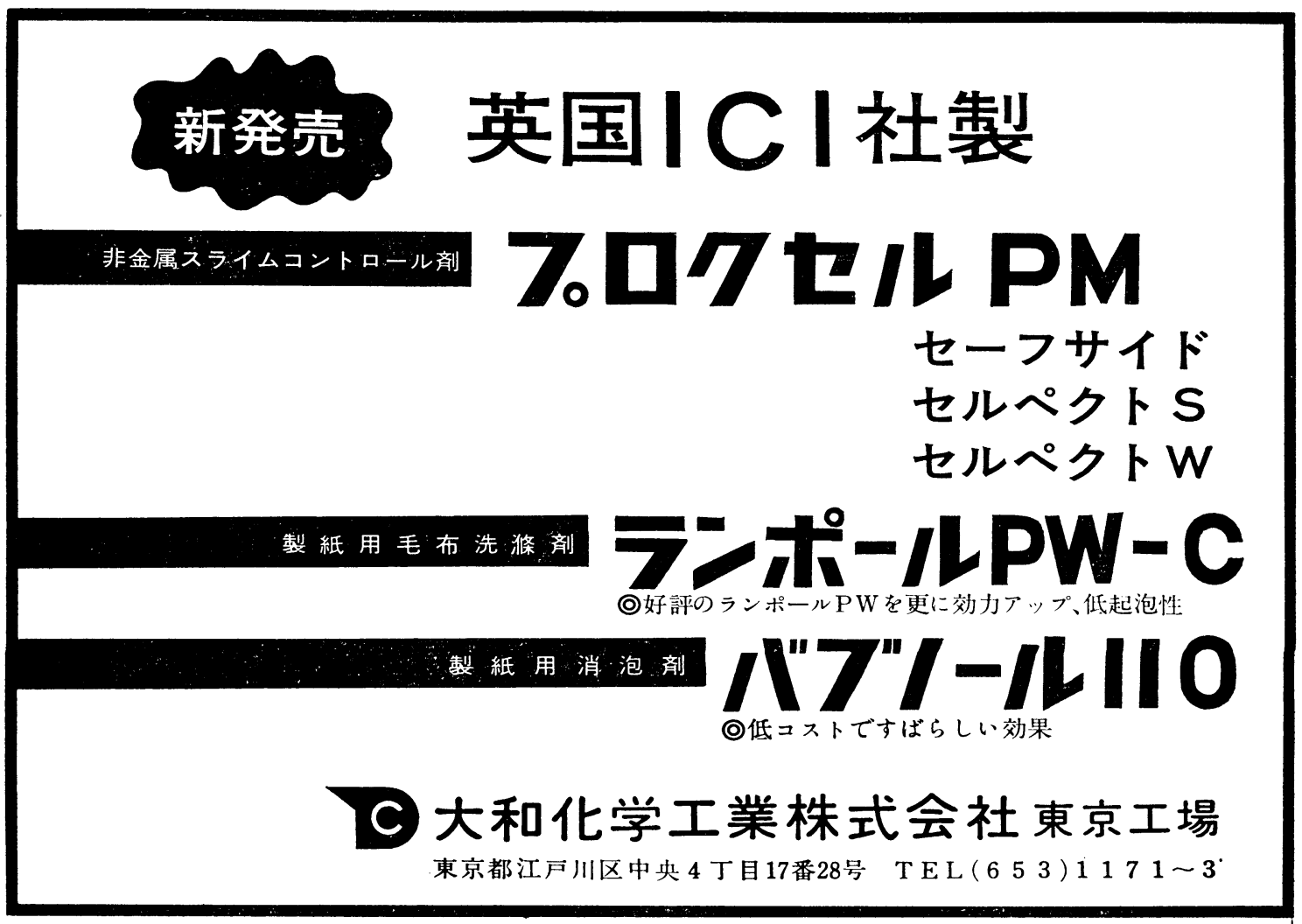

